\title{
Cholesterol embolism as a complication of left heart catheterisation Report of seven cases
}

\author{
HENK DROST, BEERT BUIS, DICK HAAN, JOOP A HILLERS \\ From the Department of Cardiology, Leiden University Hospital, Leiden, the Netherlands
}

SUMMARY Cholesterol embolism after left heart catheterisation by the femoral approach was diagnosed in seven men (mean age 59.6 years) out of a total of 4587 catheterisations. Diabetes was present in four patients, systemic hypertension in three, and signs of extensive atherosclerosis in six; five patients were taking anticoagulant drugs. Acute pain in the legs or abdomen occurred in six patients, two of whom had abdominal angina; renal failure was present in six patients, cutaneous manifestations in five, and a cholesterol embolus was seen in the retina in one. Six out of six patients had an appreciable increase in the erythrocyte sedimentation rate and five out of five had eosinophilia within a week of catheterisation. Renal failure was progressive in five patients, one of whom required haemodialysis. Three patients required amputation of the toes because of gangrene. Four patients died within four and a half months of catheterisation from causes not directly related to cholesterol embolism. At necropsy cholesterol emboli were found in all four patients. Cholesterol embolism is a rare but serious complication of left heart catheterisation.

Cholesterol embolism is not widely recognised as a complication of cardiac catheterisation ${ }^{1-5}$ and may be difficult to diagnose.$^{6-9} \mathrm{We}$ report the main findings in seven patients who suffered cholesterol embolism after left heart catheterisation.

\section{Patients and methods}

Between January 1978 and April 1982 cholesterol embolism after left heart catheterisation was diagnosed in seven men out of a total of 4587 cardiac catheterisations. Diagnosis was based on the typical clinical features of cholesterol embolism after exclusion of other causes, and in four patients was confirmed at necropsy. Table 1 summarises the clinical characteristics of the patients. In all seven patients catheterisation had been carried out because of anginal symptoms.

\section{CARDIAC CATHETERISATION}

For cardiac catheterisation the Judkins technique ${ }^{10}$

Requests for reprints to Dr Henk Drost, Department of Cardiology, Leiden University Hospital, Rijnsburgerweg 10, 2333 AA Leiden, the Netherlands.

Accepted for publication 5 April 1984 was used with polyurethane highflow Judkins catheters (Cordis) and safety guide wires (Cook) with a straight tip. In three patients (cases 2,5 , and 6) a $\mathrm{J}$ shaped tip was also used because of difficulties in advancing the guide wire. In six patients metrizoate (Isopaque Coronar, Nyegaard) was used as contrast medium and in one ioxaglate (Hexabrix, Guerbet). In accordance with our protocol for left heart catheterisation all patients received 7500 IU of heparin intraarterially just before the procedure. At the end of catheterisation heparin was neutralised by giving $75 \mathrm{mg}$ protamine chloride. The seven catheterisations were performed by four different experienced physicians.

\section{CLINICAL FEATURES}

Tables 1 and 2 summarise the clinical features. Severe pain in the legs or the lumbar or abdominal regions occurred in six patients during or shortly after left heart catheterisation. In two of them typical abdominal angina developed with positive faecal occult blood tests. Livedo reticularis on the legs or the lower half of the trunk was noted in five patients, three of whom also had acrocyanosis of the toes. Ophthalmoscopy carried out on four patients showed a cholesterol embolus in one of them. 
Table 1 Clinical features of seven patients with cholesterol embolism after left heart catheterisation

\begin{tabular}{|c|c|c|c|c|c|c|c|}
\hline & \multicolumn{7}{|l|}{ Cases } \\
\hline & 1 & 2 & 3 & 4 & 5 & 6 & 7 \\
\hline Age $(\mathrm{yr}) / \mathrm{sex}$ & $63 / M$ & $51 / M$ & $67 / M$ & $55 / M$ & $59 / M$ & $61 / M$ & $61 / M$ \\
\hline $\begin{array}{l}\text { Associated diseases } \\
\text { Atherosclerosis }\end{array}$ & + & + & - & + & + & + & + \\
\hline $\begin{array}{l}\text { Hypercholesterolaemia } \\
(>7 \mathrm{mmol} / \mathrm{l})\end{array}$ & + & - & - & - & - & - & - \\
\hline Diabetes mellitus & + & + & - & - & + & - & + \\
\hline Systemic hypertension & + & - & - & - & + & - & + \\
\hline $\begin{array}{l}\text { Taking anticoagulant drugs } \\
\text { Symptoms }\end{array}$ & + & + & - & + & + & + & - \\
\hline $\begin{array}{l}\text { Onsett } \\
\text { Pain (location) }\end{array}$ & 1 & $\begin{array}{l}20-30+ \\
-\end{array}$ & $\underbrace{2}_{\substack{\text { region } \\
\text { Lumbar }}}$ & $\begin{array}{l}0 \\
\text { Lumbar } \\
\text { region }\end{array}$ & $\begin{array}{l}0 \\
\text { Abdominal } \\
\text { region }\end{array}$ & $\begin{array}{l}2 \\
\text { Legs }\end{array}$ & $\begin{array}{l}0 \\
\text { Abdominal } \\
\text { region }\end{array}$ \\
\hline $\begin{array}{l}\text { Abdominal angina } \\
\text { Signs }\end{array}$ & - & - & - & + & - & - & + \\
\hline $\begin{array}{l}\text { Livedo reticularis } \\
\text { (location) }\end{array}$ & Legs & Abdomen & $\begin{array}{l}\text { Legs and } \\
\text { abdomen }\end{array}$ & - & - & $\begin{array}{l}\text { Legs and } \\
\text { abdomen }\end{array}$ & $\begin{array}{l}\text { Legs and } \\
\text { abdomen }\end{array}$ \\
\hline $\begin{array}{l}\text { Acrocyanosis of toes } \\
\mathrm{CE} \text { in retina }\end{array}$ & $\stackrel{+}{?}$ & $\bar{?}$ & $=$ & - & $\bar{?}$ & \pm & $\begin{array}{l}+ \\
+\end{array}$ \\
\hline Serious complications & $\begin{array}{l}\text { Amputation } \\
\text { of toes }\end{array}$ & Died\$ & Died\| & Died $\$$ & Died\$ & $\begin{array}{l}\text { Amputation } \\
\text { of toes }\end{array}$ & $\begin{array}{l}\text { Amputation } \\
\text { of toes }\end{array}$ \\
\hline
\end{tabular}

CE, cholesterol emboli; +, present; -, absent; ?, unknown.

$\star$ Denotes aneurysm(s), severe peripheral ischaemia, or previous myocardial infarction.

+ Day(s) after catheterisation ( 0 , during catheterisation).

¥Presented with general malaise caused by renal failure.

2 months after catheterisation from fatal myocardial infarction; at necropsy CE in kidneys.

f $11 / 2$ months after catheterisation postoperatively; at necropsy CE in kidneys, adrenal glands, and stomach.

A pronounced increase in the erythrocyte sedimentation rate and a slight increase in the white blood cell count with eosinophilia was a common laboratory finding, which in all cases occurred within a week of catheterisation (Table 2). Renal failure was present in six patients. No period of oliguria occurred. In four patients urine analysis showed slight proteinuria $(<0.5 \mathrm{~g} / \mathrm{l})$. Only a few granular casts and red blood cells in the urinary sediment were noted. Skin biopsy specimens taken from sites with visible skin abnor- malities in two patients failed to show cholesterol emboli. Muscle biopsy specimens were not taken.

Treatment with plasma expanders, heparin, or adrenal steroids appeared to have no influence on the course of the disease. Lumbar sympathectomy performed in one patient failed to improve the ischaemic signs in the toes. The outcome of the disorder was poor: in all three patients acrocyanosis of toes led to gangrene and amputation of the toes. Renal failure was stable in one and progressive in five patients,

Table 2 Laboratory findings before and after catheterisation in seven patients with cholesterol embolism after left heart catheterisation

\begin{tabular}{|c|c|c|c|c|c|c|c|}
\hline & \multicolumn{7}{|l|}{ Cases } \\
\hline & 1 & 2 & 3 & 4 & 5 & 6 & 7 \\
\hline $\begin{array}{l}\text { ESR (mm in first hour) } \\
\text { Before } \\
5 \cdot 0(2 \cdot 3) \text { days` after } \\
\text { WBC }\left(\times 10^{9} / 1\right)\end{array}$ & $\begin{array}{r}2 \\
74\end{array}$ & $\begin{array}{r}68 \\
118\end{array}$ & $\begin{array}{l}17 \\
51\end{array}$ & $\begin{array}{l}49 \\
89\end{array}$ & $\begin{array}{l}13 \\
42\end{array}$ & ? & $\begin{array}{l}19 \\
49\end{array}$ \\
\hline $\begin{array}{l}\text { Before } \\
5 \cdot 6(2.5) \text { days } \\
\text { Eosinophils (\% of WBC) }\end{array}$ & $\begin{array}{l}11 \cdot 5 \\
12 \cdot 1\end{array}$ & ? & $\begin{array}{r}7 \cdot 1 \\
11 \cdot 0\end{array}$ & $\begin{array}{l}11.9 \\
14.8\end{array}$ & $\begin{array}{r}7 \cdot 8 \\
11 \cdot 1\end{array}$ & $?$ & $\begin{array}{l}6.0 \\
9.4\end{array}$ \\
\hline $\begin{array}{l}\text { Before } \\
6 \cdot 4(2 \cdot 1) \text { days } \\
\text { Serum creatinine }(\mu \mathrm{mol} / /)\end{array}$ & $\begin{array}{l}2 \\
7\end{array}$ & ? & $\begin{array}{l}1 \\
5\end{array}$ & $\begin{array}{l}1 \\
3\end{array}$ & $\begin{array}{l}0 \\
6\end{array}$ & $?$ & $\begin{array}{r}4 \\
13\end{array}$ \\
\hline $\begin{array}{l}\text { Before } \\
4 \cdot 8(2 \cdot 2) \text { days }{ }^{\star} \text { after } \\
36(9) \text { days }^{\star} \text { after } \\
88 \text { (22) days } \text { after }^{\circ}\end{array}$ & $\begin{array}{l}220 \\
298 \\
302 \\
292\end{array}$ & $\begin{array}{l}79 \\
? \\
270 \\
471\end{array}$ & $\begin{array}{l}?^{94} \\
? \\
190\end{array}$ & $\begin{array}{l}137 \\
154 \\
213 \\
252\end{array}$ & $\begin{array}{l}115 \\
212 \\
237 \\
246\end{array}$ & $\begin{array}{l}125 \\
108 \\
110 \\
104\end{array}$ & $\begin{array}{l}105 \\
167 \\
807 \\
400+\end{array}$ \\
\hline
\end{tabular}

^Mean (SD).

†After haemodialysis.

?, unknown; ESR, erythrocyte sedimentation rate; WBC, white blood cell count. 


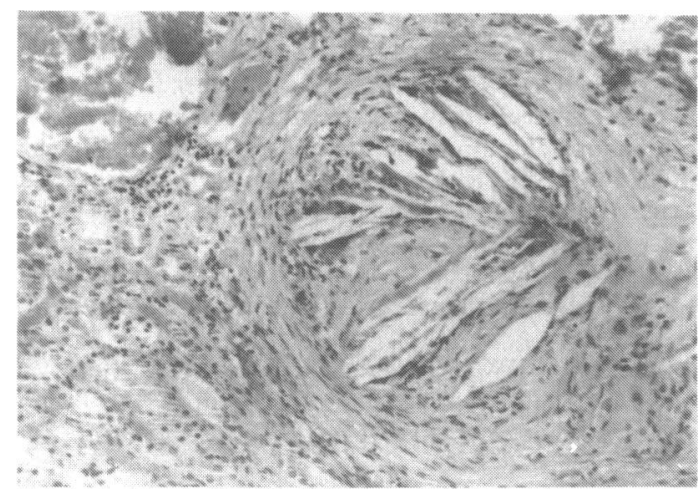

Figure Histological appearance of a necropsy specimen showing a branch of the renal artery occluded by needle shaped clefts containing embolised cholesterol crystals. (Haematoxylin and eosin stain, original magnification $\times 400$ ).

necessitating haemodialysis in one. This resulted in a slight improvement in renal function, and after nine weeks dialysis was stopped. Dialysis was resumed six months later, however, because of uraemic pericarditis. Four of the seven patients died within 2-41/2 months after catheterisation from causes not directly related to cholesterol embolism: three patients had a fatal myocardial reinfarction and one died postoperatively after resection of a thoracic aortic aneurysm. In all four cases necropsy showed many cholesterol emboli in the kidneys (Figure) and in one of them in the adrenal glands and the stomach.

\section{Discussion}

Thromboembolism due to thrombogenesis on vascular catheter surfaces or guide wires 1112 is a well known complication of cardiac catheterisation. ${ }^{1-5}$ Manipulation with a catheter or guide wire can also dislodge and spread particles containing cholesterol from the arterial wall. This complication-cholesterol or atheromatous embolism-is seldom reported in relation to cardiac catheterisation. Nevertheless, in a postmortem study of patients with atherosclerosis who died within six months of left heart catheterisation Ramirez et al detected cholesterol embolism in $25.5 \%$ of necropsy specimens. ${ }^{13}$ In an age and disease matched control group not undergoing catheterisation the incidence was only $4 \cdot 3 \%$. How often cholesterol emboli can occur without clinical symptoms is unknown.

Our findings confirm that extensive atherosclerosis, systemic hypertension, diabetes mellitus, and possibly anticoagulant treatment itself represent risk factors for the disease. ${ }^{714-16}$ The fact that we routinely use a straight guide wire for all our catheterisations and that many of our patients are receiving long term anticoagulant treatment may partly explain the relatively high incidence of cholesterol emboli in our series of catheterisations.

Cholesterol emboli can spread to almost any organ and cause a diverse clinical picture, thereby making diagnosis difficult. 17-27 Cholesterol emboli should, however, be considered when acute pain, skin abnormalities, or renal failure occur after left heart catheterisation. An increase in the erythrocyte sedimentation rate and eosinophilia support the diagnosis, which becomes more definite when cholesterol emboli are found at ophthalmoscopy and in skin, bone marrow, or random muscle biopsy specimens. ${ }^{628} 29$

The outcome of cholesterol embolism is poor; peripheral ischaemic changes often lead to gangrene and amputation, and renal failure is progressive. Until now no therapeutic measures have proved effective: adrenal steroids, aspirin, dipyridamole, low molecular dextran, and lumbar sympathectomy have been used by us and others without improvement in symptoms or signs. ${ }^{23} 30$ The role of anticoagulants is controversial ${ }^{1631}$; they may cause atherosclerotic plaque haemorrhage or prevent formation of the fibrin layer on top of the already ruptured plaque and thus increase the occurrence of cholesterol emboli. On the other hand, peripheral symptoms of ischaemia have disappeared after treatment with heparin possibly because of a decrease in superimposed thromboses. Nevertheless, symptoms were neither alleviated nor aggravated after heparin was given to one of our patients. If a definite source of the cholesterol emboli is identified-for instance an aortic aneurysm-the surgical removal of that source should be considered. ${ }^{30} 32$

We conclude that cholesterol embolism is a rare but serious complication of left heart catheterisation. Although no adequate treatment is yet known, early recognition of cholesterol emboli may at least make laborious diagnostic studies unnecessary.

\section{References}

1 Grossman W. Complications of cardiac catheterization: incidence, causes and prevention. In: Grossman W, ed. Cardiac catheterization and angiography. Philadelphia: Lea and Febiger, 1980:25-35.

2 Kennedy JW. Complications associated with cardiac catheterization and angiography. Cathet Cardiovasc Diagn 1982; 8: 5-11.

3 Gwost J, Stoebe T, Chesler E, Weir EK. Analysis of the complications of cardiac catheterization over nine years. Cathet Cardivasc Diagn 1982; 8: 13-21.

4 Davis K, Kennedy JW, Kemp HG Jr, Judkins MP, Gosselin AJ, Killip T. Complications of coronary arteriogra- 
phy from the collaborative study of coronary artery surgery (CASS). Circulation 1979; 59: 1105-12.

5 Bourassa MG, Noble J. Complication rate of coronary arteriography: a review of 5250 cases studied by a percutaneous femoral technique. Circulation 1976; 53: 10614.

6 Pierce JR Jr, Wren MV, Cousar JB Jr. Cholesterol embolism: diagnosis antemortem by bone marrow biopsy. Ann Intern Med 1978; 89: 937-8.

7 Oostinga P, Thompson J, Noordhoek Hegt V, Eulderink F. Gedissemineerde cholesterolemboli; een ziekte beeld lijkend op polyarteriitis nodosa. Ned Tijdschr Geneeskd 1978; 122: 1698-701.

8 Richards AM, Eliot RS, Kanjuh VI, Bloemendaal RD, Edwards JE. Cholesterol embolism: a multiple system disease masquerading as polyarteritis nodosa. Am $\mathcal{F}$ Cardiol 1965; 15: 696-707.

9 Haygood TA, Fessel J, Strange DA. Atheromatous microembolism simulating polymyositis. $\mathcal{F A M A} 1$ 1968; 203: 423-5.

10 Judkins MP. Percutaneous transfemoral selective coronary arteriography. Radiol Clin North Am 1968; 6: 46792.

11 Nachnani GH, Lessin LS, Motomiya T, Jensen WN. Scanning electron microscopy of thrombogenesis on vascular catheter surfaces. $N$ Engl F Med 1972; 286: $139-40$.

12 Formanek G, Frech RS, Amplatz K. Arterial thrombus formation during clinical percutaneous catheterization. Circulation 1970; 41: 833-9.

13 Ramirez G, O’Neill WM Jr, Lambert R, Bloomer HA. Cholesterol embolization: a complication of angiography. Arch Intern Med 1978; 138: 1430-2.

14 Thurlbeck WM, Castleman B. Atheromatous emboli to the kidneys after aortic surgery. $N$ Engl F Med 1957; 257: 442-7.

15 Van der Hoek C, Groenendaal JHLM, Gratama S. Choresterolembolieën; een gegeneraliseerde ziekte met eosinofilie. Ned Tijdschr Geneeskd 1979; 123: 1017-20.

16 Moldveen-Geronimus M, Merriam JC Jr. Cholesterol embolization. Circulation 1967; 35: 946-53.

17 Flory CM. Arterial occlusions produced by emboli from eroded aortic atheromatous plaques. Am F Pathol 1945; 21: 549-65.
18 Hertzer NR. Peripheral atheromatous embolization following blunt abdominal trauma. Surgery $1977 ; 82: 244-7$.

19 Kwaan JHM, Vander Molen R, Stemmer EA, Connolly JE. Peripheral embolism resulting from unsuspected atheromatous aortic plaques. Surgery 1975; 78: 583-8.

20 Anderson WR, Richards AM, Weiss L. Hemorrhage and necrosis of the stomach and bowel due to atheroembolism. Am f Clin Pathol 1967; 48: 30-8. .

21 Schinella RA, Porensky R. Atheromatous emboli associated with external cardiac massage. Arch Pathol 1974; 97: 319-22.

22 McKibbin DW, Bulkley BH, Green WR, Gott VL, Hutchins GM. Fatal cerebral atheromatous embolization after cardiopulmonary bypass. $\mathcal{F}$ Thorac Cardiovasc Surg 1976; 71: 741-5.

23 Kassirer JP. Atheroembolic renal disease. $N$ Engl F Med 1969; 280: 812-8.

24 Harrington D, Amplatz K. Cholesterol embolization and spinal infarction following aortic çatheterization. $A \mathcal{F R}$ 1972; 115: 171-4.

25 Harrington JT, Sommers SC, Kassirer JP. Atheromatous emboli with progressive renal failure. Ann Intern Med 1968; 68: 152-60.

26 Lonni YGW, Matsumoto KK, Lecky JW. Postaortographic cholesterol (atheromatous) embolization. Radiology 1969; 93: 63-5.

27 Castleman B, Scully RE, McNeely BU, eds. Case record of the Massachusetts General Hospital. Case 8-1972. N Engl f Med 1972; 286: 422-8.

28 Berkman M, Berkman N, Favre M, Seban C, Chice P. Les embolie de cholestérol: confrontation clinique, ophthalmoscopique et anatomique, à l'occasion de trois observations. Nouv Presse Med 1972; 1: 795-800.

29 Anderson WR, Richards AM. Evaluation of lower extremity muscle biopsies in the diagnosis of atheroembolism. Arch Pathol 1968; 86: 535-41.

30 Schechter DS. Atheromatous embolization to lower limbs. NY State f Med 1979; 79: 1180-6.

31 Perdue GD Jr, Smith RB III. Atheromatous microemboli. Ann Surg 1969; 169: 954-9.

32 Brenowitz JB, Edwards WS. The management of atheromatous emboli to the lower extremities. Surg Gynecol Obstet 1976; 143: 941-5. 